\title{
Relevance of the balanced scorecard model in Africa: Shareholder-centred or stakeholder-centred?
}

\author{
James Kamwachale Khomba ${ }^{1 *}$, Frans NS Vermaak ${ }^{2}$ and Rabiya Hanif ${ }^{3}$ \\ ${ }^{1}$ Department of Management Studies, University of Malawi, Private Bag 303, Blantyre 3, Malawi. \\ ${ }^{2}$ Department of Financial Management Sciences, University of Pretoria, 0002 Pretoria, Republic of South Africa. \\ ${ }^{3}$ Department of Accountancy, University of Malawi, Private Bag 303, Blantyre 3, Malawi. \\ Accepted 28 February, 2012
}

\begin{abstract}
The balanced scorecard model that was invented by Kaplan and Norton (1992) in the USA was designed for Western countries that operate within a capitalistic system. The capitalist systems focus on maximisation of wealth for the financial capital providers, shareholders. Africa is different in that its socio-cultural framework is socialist, community-based and humanist in nature. Thus, the balanced scorecard model is not fully reconcilable with an African environment. This study aimed at establishing whether or not the balanced scorecard model is relevant to an organisation operating in Africa. The study results reveal that the African social-cultural framework is inclusive in that its corporate governance embraces all stakeholders unlike an exclusive western framework of corporate governance that focuses on shareholders only. The current conceptualisation of the Norton and Kaplan balanced scorecard model is not ideal for an organisation operating in an African environment. There is a need to redesign the current balanced scorecard model to reflect realities of the African socio-cultural framework.
\end{abstract}

Key words: Africa, Malawi, South Africa, Ubuntu, balanced scorecard, Shareholder, Stakeholder.

\section{INTRODUCTION}

The Kaplan and Norton (1992) balanced scorecard model was developed to balance financial and non-financial measures within the corporate planning and performance measurement systems. The aim of the model was to add leading measures that represent indicators of future financial performance to traditional financial measures, which are based on past performance and are in fact lagging measures.

The balanced scorecard model (Kaplan and Norton, 1992) emphasises the need for an information set that covers all relevant areas of corporate performance measurement systems. The information that the model requires is premised on the financial perspective, and adds three more non-financial perspectives, namely the customer satisfaction, internal business processes, and innovation perspectives. In this way, the model balances

\footnotetext{
*Corresponding author. E-mail: jkkhomba@gmail.com.
}

financial and non-financial performance measures. These four perspectives are balanced in the sense that organisations are required to think in terms of all the four perspectives holistically to prevent a situation in which improvements are made in one area at the expense of another.

Under the balanced scorecard model senior management start, in articulating their corporate strategies, by looking at how improving employee capabilities and skills in certain job positions (innovation perspective) would enable a critical internal business process to improve as well (Kaplan and Norton, 2004). It follows that the improvement of internal business processes would cascade down to enhance the value proposition delivered to targeted customers. By implication, the improved customer base would ultimately lead to increased revenues and ultimately significantly higher shareholder value. The explicit cause-and-effect relationships among the objectives in the four perspectives of the balanced scorecard model translate 
into a strategy map, as shown in Figure 1 (Kaplan and Norton, 2004).

The strategy map enhances the link between the cause-and-effect and corporate objectives and provides the visual framework for integrating the organisation's objectives of maximising the shareholders' wealth through the four perspectives of the balanced scorecard model (Dasgupta, 2010; Kaplan et al., 2010). Further, the strategy map allows senior executives and managers to see how attaining corporate objectives at the departmental or employee level assists an organisation to achieve better internal business processes, customer satisfaction and ultimately its financial objectives of maximising the shareholders' wealth (Chan, 2009; Wu and Liu, 2010).

Despite its holistic approach, the balanced scorecard model has some limitations. The model was designed for Western societies, which are characterised by a mechanistic, capitalist system that emphasises the maximization of shareholders' wealth in terms of profitability, rather than addresses other critical stakeholders' needs, such as government, suppliers, the local community and the natural environment (Bourguignon et al., 2004; Voelpel et al., 2006).

For instance, African countries differ from countries in which Western economies are dominant with regard to dimensions such as infrastructure, literacy levels, markets and customers, sources of capital, government intervention and socio-cultural frameworks (Broodryk, 2007). In Africa, the Umunthu or Ubuntu (humanness) principles, which are essentially socialist and humanist in nature, apply and they are considered critical ingredients for the success of any organisation in Africa (Mangaliso, 2001). Africa has its own unique socio-cultural settings, which have a direct impact on people-centred systems that are premised on caring and sharing (Khomba et al., 2011).

Further, industrial experiences from different parts of the world have been diverse. In the West especially in North America and Continental Europe, the model has been associated with some success stories (Kohnen, 2008; Niven, 2008). In other cases including those from Africa, the Balanced Scorecard model has registered numerous failure rates (Bourguignon et al., 2004: 109; DeBusk and Crabtree, 2006).

One of the explanations to the success or failure of the Balanced Scorecard model would be based on the corporate managers' capability to comprehend and let alone use the founding concepts of the model including its socio-cultural underpinnings. To a large extent, management tools are coherent with the local briefs and ideologies in the society of origin (Binedell, 1994; Gichure, 2006; Gouws, 1996; McFarlin et al., 1999). To some extent, locally developed management models tend to be aligned with the specific beliefs of the local society. Thus, the socio-cultural assumptions of any management model transferred from one place to another may be more or less coherent with the ideologies of the new society.

The afore-mention analysis demonstrates that there is a need for business models to synchronise with societal dimensions and ideologies for them to be successfully implemented. Similarly, Western philosophical theories and systems (such as the balanced scorecard model) that are transferred to an African society are likely to face serious socio-cultural mismatches. Such Western theories may ultimately not succeed in providing everlasting solutions to local business challenges that an organisation in Africa may be facing.

\section{RESEARCH PROBLEM AND OBJECTIVE}

The balanced scorecard model was designed for Western countries that operate within a capitalistic system. Africa is different in that it operates under a socio-cultural framework that is more humanist, community-based and socialist. Thus, the balanced scorecard model that is conceptualised for a predominantly capitalistic western society may not be fully reconcilable with an African environment. Therefore, the study aimed at establishing whether or not the application of the balanced scorecard model is relevant to corporations operating in Africa.

\section{DIFFERENCES IN SOCIO-CULTURAL IDEOLOGIES}

The balanced scorecard model was founded in USA by Kaplan and Norton in 1992. Conceptually, the balanced scorecard model is founded on and designed for the western countries that operate within a capitalistic system. Under capitalism, maximisation of shareholder's wealth is considered as the sole reason for existence of any corporation (Bourguignon et al., 2004; McNamee, 1993; Voelpel et al., 2006). Capitalistic management approaches are individualistic and mechanistic in nature in that they over-emphasise upon the prime importance of shareholders thereby sidelining other even more critical stakeholders such as suppliers, government, the local community and the natural environment (Khomba, 2011).

Socially and demographically, Africa is different from the western economies in many dimensions that include infrastructural systems, literacy levels, markets and customers, sources of capital and capital structures, government interventions, and socio-cultural underpinnings. For instance, whilst the western society is considered individualistic and capitalistic in nature (Bourguignon et al., 2004; Voelpel et al., 2006), the Africa environment is socio-culturally unique in that it is community-based, humanistic and socialistic in nature (Broodryk, 2007; Mangaliso, 2001; Mbigi and Maree, 2005). 


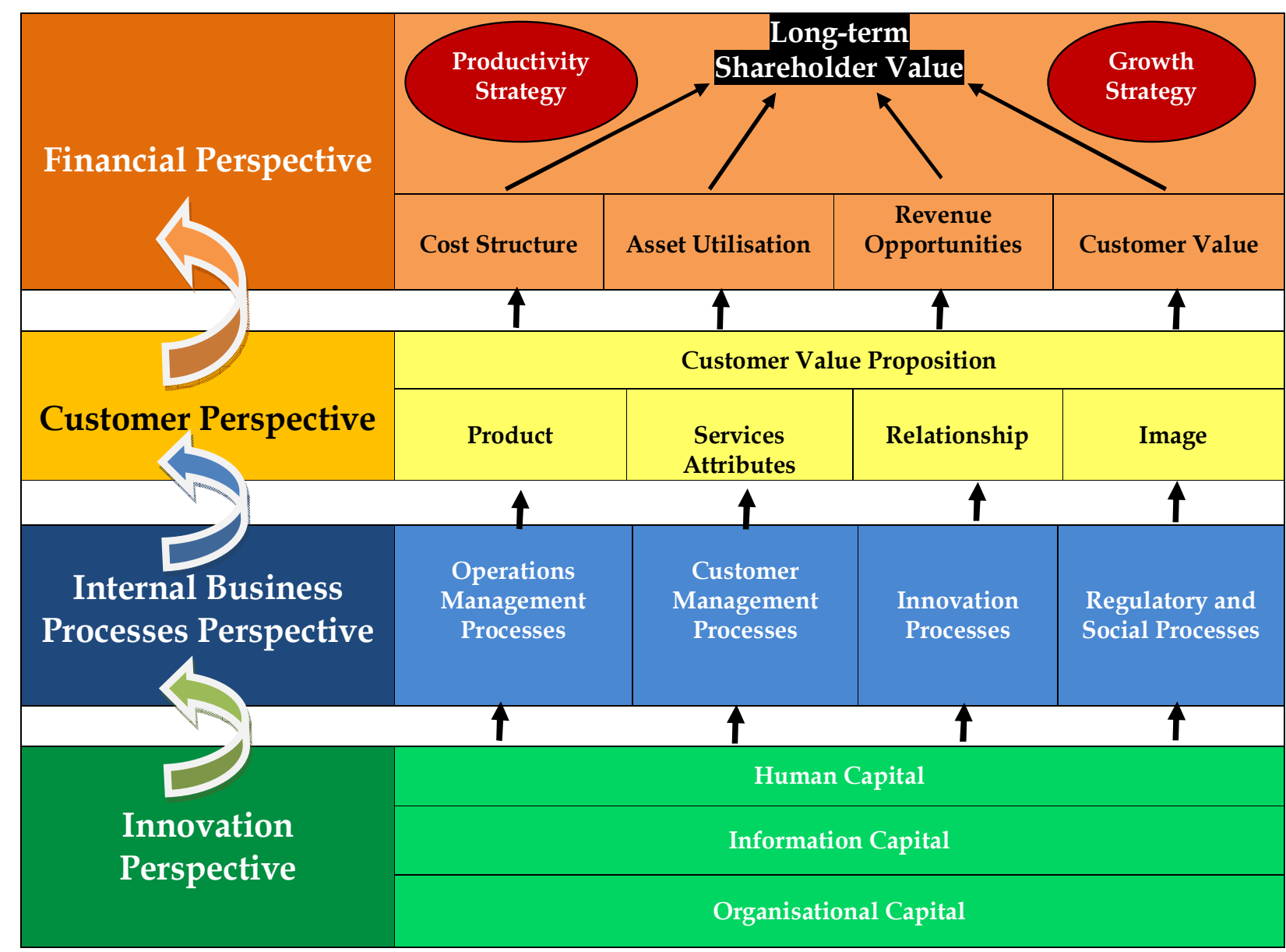

Figure 1. The strategy map represents how an organisation creates value. Source: Kaplan and Norton (2004).

Within an African environment, socio-cultural underpinnings rigorously apply and the African Umunthu or Ubuntu (humanness) philosophies are omnipresent throughout the continent. Therefore, the Ubuntu sociocultural dimensions, which are essentially socialistic and humanistic, apply and are considered critical in any African organisation (Mangaliso, 2001; Mbigi and Maree, 2005). Africa has its own unique socio-cultural settings, which have a direct impact on people-centred systems, including corporate performance (Khomba et al., 2011). Thus, the socio-cultural diversity premised on the use of western management systems should pose a great deal of challenge within an Africa-based organisation.

\section{SCORECARDS SURROUNDING THE UBUNTU PHILOSOPHY}

Voelpel et al. (2006) warn that the de-emphasis of sociocultural perspectives is a serious flaw in the balanced scorecard model. In order to align the scorecard with an African context, indigenous beliefs and values must be conceptualised into the new perspectives. Though the selected aspects of management theories developed in the west may well apply to the African context, the adoption of such foreign practices should be contingent upon contextual circumstances in the adopting society (Darley and Blankson, 2008; Ghebregiogis and Karsten, 2006; Gray et al., 2008). Management scholars and executive managers appear to be confident that using western cultural management models in African countries is appropriate, but this confidence may be misplaced. In Africa, the Ubuntu is the basis of African social laws, encompassing social values such as solidarity, caring and sharing (Binedell, 1995; English, 2002; Moloketi, 2009).

The Ubuntu philosophy is integrated into all aspects of day-to-day life throughout Africa. The Ubuntu philosophy embodies the ethics that defines Africans and their social behaviours (Battle, 1997; Eze, 2006; Mangaliso, 2001). Africans as social beings are in constant communion with one another, where a human being is regarded as a human being only through his or her relationships to other human beings. The survival of a human being depends on other people - the community and society. The worth of every person depends on social, cultural 
and spiritual criteria. It is this interconnectedness and interdependence that makes the African framework complete.

Organisations that operate in Africa need to have a clear understanding of the African framework, including historical, political, legal, educational, economic and competitive factors influencing corporate operations in order for them to be effective (Binedell, 1994; McFarlin et al., 1999; Khomba et al., 2011). Hence, African countries need to develop their own unique approaches that are appropriate to their respective environments. Thus, there must be a proper identification of the African indigenous philosophies and values that underlie the African context. Within the indigenisation spirit, the new African management systems dictate that culture be incorporated into the organisational set-up for there to be an effective and productive system (Mangaliso, 2001; Mangcu, 2007; Shubani, 2007).

\section{WESTERN AND AFRICAN CORPORATE GOVERNANCE}

Within the Western/African ideological differences, there have been varied views about the roles of corporations (Rossouw, 2009). Such varied views have given rise to different ways on how organisations are managed or governed (corporate governance) in different parts of the world. There are several corporate governance regimes around the world that are founded by different sets of socio-cultural frameworks of the founding societies. Additionally, corporate governance regimes are also directed by the question: For whose benefit should corporations be governed?

On one hand, corporate governance regime that is experienced in the USA is that organisations are perceived to be pursuing financial interests of shareholders (Rossouw, 2009). Thus, the USA marketplace is strongly associated with a shareholdercentred approach as it is exclusive towards satisfying the shareholders motive of maximising profits.

On the other hand, there is a stakeholder-centred broader view of organisations in Africa. The African perspective ethic of corporate governance is mostly grounded by an inclusive ethic of governance which signifies that an organisation has explicit commitment to serve the interests of both the shareholders and other non-shareholding stakeholders (West, 2009). Such organisational commitment to a stakeholder-centred approach towards corporate governance is grounded on the African socio-cultural values as discussed earlier.

Therefore, it is not surprising that the balanced scorecard model leans towards the American exclusive shareholder-centred approach towards corporate governance which may not be fully in resonance with an African inclusive approach towards corporate governance.

\section{CONCEPTUAL FRAMEWORK OF STAKEHOLDER RELATIONSHIPS AND NETWORKS}

In order to understand the African environment better, Khomba (2011) developed a conceptual framework stakeholder relationships and networks that summarises community-type relationships of an organisation with its key stakeholders and the relationships of the stakeholders themselves as indicated in Figure 2.

In summary, the conceptual framework for an organisation in Africa depicts organisational interactions and stakeholder relationships at different layers of systems. There are four systems layers within the conceptual framework comprising (1) the corporate level representing internal activities including those of management and employees, (2) the industry level represents the boundary within which similar business by different companies operate. Within the industry level, there are customers, shareholders, government, suppliers, regulatory bodies, and competitors, (3) the Ubuntu community level represents a larger grouping of all industries where different final consumers are resident, and (4) the ecological (natural environmental) level for the largest ecosystems where natural resources are sourced. On the daily basis and in a very complex way, different stakeholders interact with an organisation for different business transactions.

\section{RESEARCH METHODOLOGY}

The study was conducted through primary research using structured questionnaire. The researchers followed basic procedures that are employed when developing the Likert scale questionnaire to measure different perceptions of managers from the commercial sector. The formulated statements on the structured questionnaire were based on procedures recommended by Saunders et al. (2003). The main steps that were followed when formulating the questionnaire included the identification and generation of perspectives surrounding corporate performance and performance measurement systems, careful review of literature on the topical area, a review of similar questionnaires that were used in prior surveys, and insights gained from an examination of latest information gathered through the internet, newspapers, magazines, TV and radio broadcastings. All these culminated into the formulation of the attitudinal statements that represented main variables of the study.

\section{Data collection}

Empirical data were collected by means of a survey. The results were used for an empirical analysis of the research findings. A structured questionnaire was designed, guided by the research problem and research objective. The questionnaire focused on variables that would assess the relevance of the balanced scorecard model within an African framework.

\section{Questionnaire structure}

To make the questionnaires user-friendly, the researchers formulated statements whose response would use nominal settings 


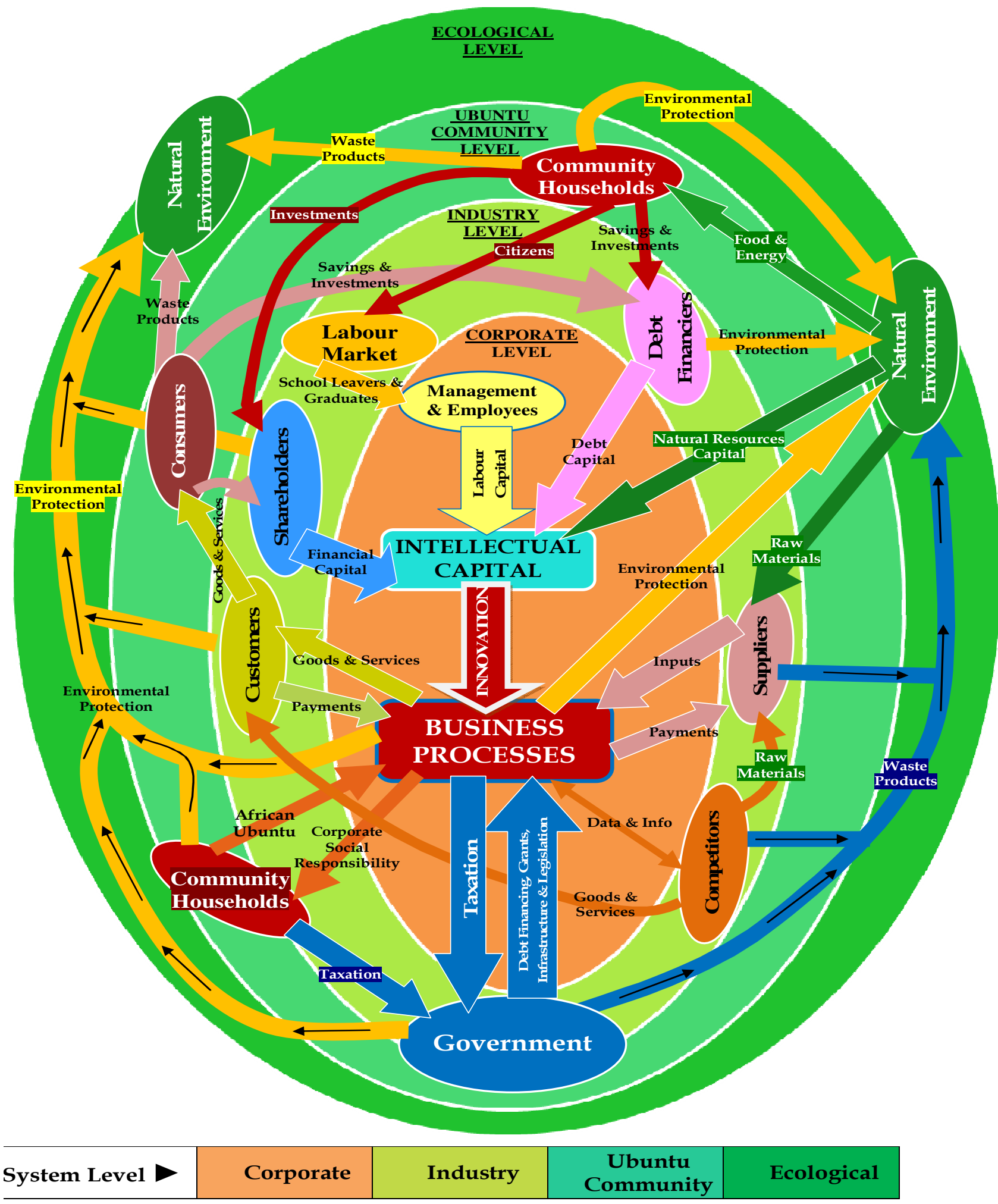

Figure 2. A conceptual framework of stakeholder relationships and networks. Source: Khomba (2011).

(Middle/Senior Management, Yes/No), ordinal settings such as the rank orders, and interval settings based on the Likert-style rating scales with the rankings signifying the degree of agreement ranging from a scale of "1" referring to "Strongly Disagree" to a scale of "5" 
referring to "Strongly Agree" on a five-point rating scale of the structured questionnaire. A five-point scale was used to assess validity as to the extent of agreement on each statement.

In Likert scales, it is assumed that all participants will perceive "Strongly Agree" as expressing greatest favour or agreement towards the attitude statements than "Somehow Agree" and "Strongly Disagree" (Babbie and Mouton, 2007; Saunders et al., 2003; Welman et al., 2005). The same order of response categories was maintained so as not to confuse respondents, as recommended by Dillman (2000). Managers were asked to rate their responses on the continuum scale that they were given. The questionnaire also assisted in the formulation of an objective and scientific report of the study findings.

\section{Pretesting}

After the questionnaire had been designed, it was pre-tested by means of several personal interviews with senior managers to ascertain the validity of the content of measures. Pretesting involved the construction of variables based on the theoretical nature of the constructs. An extensive pre-testing process was done to iron out any errors that could have arisen during the formulation of the initial questionnaire. A sample of 20 respondents was used during the pre-testing process for the questionnaire.

After the questionnaire had been validated, the pre-testing interviews allowed for the clarification and redefinition of survey items and for the rectification of any potential deficiencies where necessary. Variables with similar distributional properties had to be checked to improve the reliability of the data as recommended by Field (2009). The final structured questionnaire for the study was then formulated as shown in Appendix 1.

\section{Sampling}

The structured questionnaire was administered in both hard copy and an electronic format. Electronic questionnaires were emailed to potential respondents and the hard copy versions were posted to the respondents and then these were followed up for any feedback. Reminder telephone calls were made and e-mails were sent after every two weeks for three months of the questionnaire survey.

Large corporations were randomly selected from those that are registered with the registrar of companies or Malawi stock exchange in Malawi and those companies that are registered with the Johannesburg stock exchange or the Johannesburg Chamber of Commerce in South Africa. Though not in majority, some companies from other countries were reached through their diplomatic missions that are resident in either in Malawi or South Africa.

During data collection, a total of 620 questionnaires were dispatched to various organisations from the commercial sector in Malawi, South Africa and other African countries. Out of the 620 questionnaires, 387 responded to the questionnaire giving a final response rate of $62.4 \%$. The sampling statistics show that the Kaiser-Meyer-Oklin measure of sampling adequacy is 0.856 which is a "great" value for verification of sampling adequacy for the analysis (Field, 2009). Thus, the afore-mentioned analysis confirms the factorability of items and adequacy of the sample for conclusive results (Chenhall, 2005; Field, 2009; Hanafizadeh and Sorousha, 2008).

\section{Country of participating organisations}

Demographics of participating organisations $(\mathrm{N}=387)$ indicate that 168 respondents (43.4\%) were from South Africa, 187 respondents (48.3\%) were from Malawi, and 32 (8.3\%) respondents were from other African countries that included Zimbabwe, Mozambique, Lesotho, Botswana and Zambia. As reflected in the statistics, the majority $(94.7 \%)$ of respondents came from Malawi and South Africa combined with 5.3\% from other African countries.

\section{Data reliability and validity}

Data reliability as a measure of internal consistency of the data constructs was determined by means of the Cronbach alpha $(\alpha)-$ an $\alpha$ coefficient above 0.7 is considered reliable (Bryman and Bell, 2007; Costello and Osborne, 2005; Field 2009). In this study, the overall $\alpha$ coefficient was $\alpha=0.874$, which suggests that the internal consistency of the data constructs was excellent.

Further analysis of Cronbach's alpha coefficients of the 'Scale if item deleted' gives values that are not significantly different from the original $\alpha=0.874$. The new values of the 'scale if item deleted' range from $\alpha=0.868$ to 0.901 signifying that the questionnaire is reliable and that the deletion of any variable cannot significantly affect the original Cronbach's alpha coefficient of $\alpha=0.874$.

In terms of data validity, researchers were careful in sampling the targeted population. Though randomly done, the questionnaire was targeted at large corporations by focussing on business executives at senior management $(60.7 \%$ of respondents) and middle management $(37.0 \%$ of respondents), and other business executives including the board members (2.3\%). Such business executives include the chief executive officers (CEOs), chief financial officers (CFOs), financial managers, management accountants, and company secretaries who are conversant with issues raised under the study; hence maintaining homogeneity of the sample. Still more, a total of $71.3 \%$ of the respondents have industrial work experience of more than six years.

The statistics indicate that the Bartlett test of sphericity $\chi^{2}(1326)$ $=10479.92, p<0.001$ was significant for all factors indicating that we can be confident that multicolinearity does not exist under these survey data and that factor analysis is appropriate according to Field (2009). Thus, the Bartlett's test of sphericity $\chi^{2}(1326)=$ $10479.92, p<0.001$ signifies that the study results are valid for any conclusive analysis and discussions.

\section{ANALYSIS AND DISCUSSION OF RESEARCH RESULTS}

Ratings on each statement were done through univariate analysis by using individual rating statistics and frequency tables. Overall, the analysis shows that there were varied responses from participants regarding the extent of their agreement on each of the questionnaire statements. This aspect reports on the study results and analysis of ratings on the questionnaire statements.

Statement 1: Our organisation puts more emphasis on maximisation of shareholders wealth than of other stakeholders' wealth.

This focus of the questionnaire statement aimed at assessing the application of the popular maxim of "shareholder wealth maximisation" that is the beginning and end of shareholder-centred management theories. The study findings reveal that only $45.5 \%$ agree $(24.3 \%$ "Agree" and 21.2\% "Strongly agree") that their organisations put more emphasis on the maximisation of shareholders' wealth than on other stakeholders' wealth. 
A total of $27.9 \%$ disagree, whilst $26.6 \%$ "Somehow agree" with the statement.

The analysis of the study findings indicates that there are few companies in Africa that are inclined towards focusing their operations on maximisation of the shareholder value rather than look at value for other stakeholders too. The analysis also reveals that many African companies embrace the stakeholder-centred approach within corporate planning and performance measurement systems. The research findings conform with studies by Rossouw (2009) where the African governance ethic is inclusive (stakeholder-centred) rather than the exclusive shareholder-centred by the Western society. The afore-mentioned analysis also confirms the provisions of the earlier conceptual framework (Khomba, 2011) which is inclusive and stakeholder-centred.

Statement 2: We treat employees as the most valuable asset of our organisation

The majority agree that they treat their employees as the most valuable assets of their organisation. A total of $73.6 \%$ agree $(34.6 \%$ "Agree" and $39.0 \%$ "Strongly Agree") with the statement, $10.6 \%$ disagree, whilst $15.8 \%$ "Somehow agree" with the statement. This analysis indicates that most organisations in Africa value their employees as a sole source of the human resources for their operations.

Recognising employees as valuable assets creates an environment conducive to more employee participation, resulting in higher levels of productivity and better corporate performance. The study findings are in conformity with the conceptual framework of stakeholder relationships and networks confirming that many African companies employ the stakeholder-centred approach within their corporate planning and performance measurement systems.

Statement 3: We recognise the interdependence of relationships of our stakeholders

There seems to be a general understanding that an organisation can succeed only if all stakeholders are recognised as members of and contributors to corporate performance, as reflected in the conceptual framework. All the respondents agreed (45.2\% "Agree", 46.5\% "Strongly agree" and 8.3\% "Somehow agree"). The analysis thus indicates that the majority of contemporary managers in Africa take cognisance of the stakeholdercentred approach in their operations. Thus, stakeholdercentred management models would be appropriate for the African framework.

The afore-mentioned analysis confirms the provisions regarding the interconnectedness of organisational stakeholders that is acknowledged by practising organisations in Africa. The study results also confirm the provisions of the conceptual framework of this study, which is inclusive and stakeholder-centred. These research findings also resonate with those of Rossouw (2009).

Statement 4: Our profitability success is a result of inputs from various stakeholders

The afore-mentioned statement was aimed at evaluating the organisation's recognition of stakeholder involvement in the value creation activities of the corporation. The vast majority of the respondents recognise that their profitability bottom line is a result of inputs from different stakeholders from within and outside the organisation. Thus, a vast majority of $81.9 \%$ agree $(47.0 \%$ "Agree" and $34.9 \%$ "Strongly agree") with the statement that corporate profitability is a result of inputs from various stakeholders, while only $3.9 \%$ disagree and $14.2 \%$ "Somehow agree".

This analysis indicates that most organisations recognise significant contributions by different stakeholders towards their operations. This result is in line with the inclusive nature of African management systems. These research findings also support the conceptual framework (Khomba, 2011), which recognises the interconnectedness and inter-dependence of different stakeholders of an organisation.

Statement 5: Our primary goal of external reporting is to contribute to an ongoing stakeholder dialogue

Apart from open communication and feedback systems, the study also aimed at assessing the extent of the external reporting systems that are intended to meet stakeholders' informational needs. The study results reveal that a majority of $78.1 \%$ of the respondents agreed (40.6\% "Agree" and 37.5\% "Strongly disagree") that their external reporting systems are primarily meant to maintain stakeholder dialogue with the respective corporations. Only 2.8\% disagree, whilst $19.1 \%$ "Somehow Agree" with the aforesaid statement.

The afore-mentioned analysis indicates that the majority of managers take cognisance of good stakeholder dialogue, which is achieved through external reporting systems. The study analysis reveals that stakeholder relationship is supreme within an African framework. It is believed that such an approach would enhance cooperation and active participation amongst different stakeholders who would be fully aware of corporate operations and overall performance.

Statement 6: We treat our suppliers as an integrated part of our business

The balanced scorecard model tends to ignore suppliers as an important ingredient into corporate performance. This statement was aimed at assessing the level of integration that corporation put with regard to suppliers. The study results disclose that $72.8 \%$ Agree $(33.3 \%$ 
"Agree" and 39.5\% "Strongly agree") that their suppliers are integrated into their business processes as strategic partners. Only $0.3 \%$ of the respondents "Disagree", whilst 26.9\% "Somehow Agree" with the aforesaid statement. The analysis demonstrates that most corporations recognise the need for running their operations with a supplier, in mind as suppliers are the sole providers of raw materials and other inputs for the production of goods and services.

It can therefore be expected that there are healthy supplier relationships in most companies in Africa. It is reflected in the research findings that most organisations realise the significance of supplier integration into business processes that are stakeholder-centred. However, the recognition of a supplier as a stakeholder is not fully highlighted in the balanced scorecard model (just implied under the internal business process perspective). Thus, the model will have to be redesigned to accommodate these findings about a supplier as a stakeholder towards business operations if at all it is to be meaningful within an African framework.

Statement 7: All stakeholders receive sufficient benefits to assure their continued collaboration with our organisation

The research findings show that a total of $69.7 \%$ Agree (43.9\% "Agree" and $25.8 \%$ "Strongly agree") that their stakeholders are given sufficient benefits by the organisation to ensure that there is continued stakeholder collaboration within its operations. Only $8.3 \%$ disagree, while $22.0 \%$ "Somehow agree" with the above statement.

These research findings indicate that most organisations believe that sufficiency in the allocation of organisational wealth would be a motivating factor that ultimately enhances long-term cooperation and collaboration by different stakeholders. Such stakeholder collaboration would also promote long-term corporate sustainability, which is the premise of the conceptual framework of stakeholder relationships and networks. Apart from the shareholders, allocation of corporate wealth to other stakeholders is not sufficiently covered under the balanced scorecard model.

Statement 8: We demonstrate mutual respect with our competitors

Modern business philosophy proposes formation of strategic partnerships, including ones with competitors (David, 2005). The study results reveal that $66.2 \%$ Agree (37.0\% "Agree" and $29.2 \%$ "Strongly agree") that they demonstrate mutual respect for competitors in their industry. Only $8.3 \%$ disagree, whilst $25.6 \%$ "Somehow agree" that they show mutual respect for the competition. The high levels of mutual respect maintained with competitors show that most organisations recognise competition as a way to foster benchmarking for continuous improvement of their products and services.

Statement 9: We constantly interact with and help the local community in which we operate

The assessment was aimed at establishing the extent of the relationship between an organisation and the local community in which business operations take place. The vast majority of $63.3 \%$ agree with that they constantly interact with and help the local community in which we operate. Only $13.7 \%$ of corporations do not. Of the respondents, 23.0\% "Somehow agree" that they constantly interact with the local communities within which their businesses operate.

The analysis demonstrates that only few organisations in Africa are not involved in helping their local communities. With full sensitisation, one would expect full compliance with corporate citizenship obligations, which include sustainability reporting, as recommended by the King III Report (Institute of Directors in Southern Africa, 2009).

Statement 10: Government contributions are foundational to our business operations

The study findings show that a total of $56.0 \%$ agree $(27.6 \%$ "Agree" and 28.4 "Strongly agree") that government contributions are regarded as foundational to corporate operations. The study results reveal that 33.3\% disagree with the statement, while $10.6 \%$ "Somehow agree". The research findings confirm the provisions of the conceptual framework (Khomba, 2011), where government is recognised as one of the key players towards business success. The government provides grant and debt financing, business infrastructural systems, and legislation. Reflected in the analysis is that government forms a critical element towards the success of corporations in Africa and should be treated as a strategic business partner.

Further stakeholder analysis shows that an overwhelming majority of $91.5 \%$ of respondents indicated that they see government as a critical stakeholder towards their operations. However, the aforesaid study findings are contrary to the provisions of the balanced scorecard model, which does not fully recognise government as a major contributor towards business operations and their success.

The afore-mentioned univariate analysis of the 10 statements on the survey questionnaire is summarised in Table 1. The means of the response ratings for each statement are diagrammatically presented in Figure 3 , overleaf.

The graph in Figure 3 indicates that Statement 1: "Our organisation puts more emphasis on maximisation of shareholders wealth than of other stakeholders wealth" ( $\mu$ = 3.31) and statement 10: "Government contributions are foundational to our business operations" ( $\mu=3.37)$ 
Table 1. Statistical summary of the univariate analysis on response ratings on questionnaire statements.

\begin{tabular}{|c|c|c|c|c|c|c|c|}
\hline Questionnaire statement & $\begin{array}{l}\text { Strongly } \\
\text { disagree }\end{array}$ & Disagree & $\begin{array}{c}\text { Disagree } \\
\text { (total) }\end{array}$ & $\begin{array}{l}\text { Somehow } \\
\text { agree }\end{array}$ & $\begin{array}{l}\text { Agree } \\
\text { (total) }\end{array}$ & Agree & $\begin{array}{c}\text { Strongly } \\
\text { agree }\end{array}$ \\
\hline $\begin{array}{l}\text { Our organisation puts more emphasis on } \\
\text { maximisation of shareholders wealth than } \\
\text { of other stakeholders wealth }\end{array}$ & 7.5 & 20.4 & 27.9 & 26.6 & 45.5 & 24.3 & 21.2 \\
\hline $\begin{array}{l}\text { We treat employees as the most valuable } \\
\text { asset of our organisation }\end{array}$ & 3.6 & 7.0 & 10.6 & 15.8 & 73.6 & 34.6 & 39.0 \\
\hline $\begin{array}{l}\text { We recognise the interdependence of } \\
\text { relationships of our stakeholders }\end{array}$ & 0.0 & 0.0 & 0.0 & 8.3 & 91.7 & 45.2 & 46.5 \\
\hline $\begin{array}{l}\text { Our profitability success is a result of } \\
\text { inputs from various stakeholders }\end{array}$ & 0.0 & 3.9 & 3.9 & 14.2 & 81.9 & 47.0 & 34.9 \\
\hline $\begin{array}{l}\text { Our primary goal of external reporting is to } \\
\text { contribute to an ongoing stakeholder } \\
\text { dialogue }\end{array}$ & 0.0 & 2.8 & 2.8 & 19.1 & 78.1 & 40.6 & 37.5 \\
\hline $\begin{array}{l}\text { We treat our suppliers as an integrated } \\
\text { part of our business }\end{array}$ & 0.3 & 0.0 & 0.3 & 26.9 & 72.8 & 33.3 & 39.5 \\
\hline $\begin{array}{l}\text { All stakeholders receive sufficient benefits } \\
\text { to assure their continued collaboration } \\
\text { with our organisation }\end{array}$ & 0.8 & 7.5 & 8.3 & 22.0 & 69.7 & 43.9 & 25.8 \\
\hline $\begin{array}{l}\text { We demonstrate mutual respect with our } \\
\text { competitors }\end{array}$ & 1.6 & 6.7 & 8.3 & 25.6 & 66.2 & 37.0 & 29.2 \\
\hline $\begin{array}{l}\text { We constantly interact with and help the } \\
\text { local community in which we operate }\end{array}$ & 1.3 & 12.4 & 13.7 & 23.0 & 63.3 & 39.0 & 24.3 \\
\hline $\begin{array}{l}\text { Government contributions are } \\
\text { foundational to our business operations }\end{array}$ & 13.7 & 19.6 & 33.3 & 10.6 & 56.0 & 27.6 & 28.4 \\
\hline
\end{tabular}

$\mathrm{N}=387$.

register very low means on the response ratings. These low means demonstrate that few respondents agree with statement 1 (45.5\%) and statement $10(56.09 \%)$, as earlier discussed.

Further examination of the graph also shows that statement 3: "We recognise the interdependence of relationships of our stakeholders" $(\mu=4.38)$ registers the highest mean on the response ratings. This indicates that a vast majority of respondents (91.7\%) agreed with statement 1. Ratings on the other statements are above average $(\mu>3.5)$ indicating that the responses are positive enough. The high ratings on the afore-mentioned statements are indicative of how seriously organisations in Africa take issues of stakeholder-centred approach. This is contrary to an exclusive shareholder-centred approach of Western society which is representative of the balanced scorecard model.

As observed, respondents generally agreed with the survey statements $(\mu>3.50)$, as displayed in, in Figure 3. The analysis also reveals that the survival of business in an Africa is premised on the continued interaction and dialogue between an organisation and all its stakeholders and not necessarily on only shareholders as is the ultimate premise of the Balanced Scorecard model. 


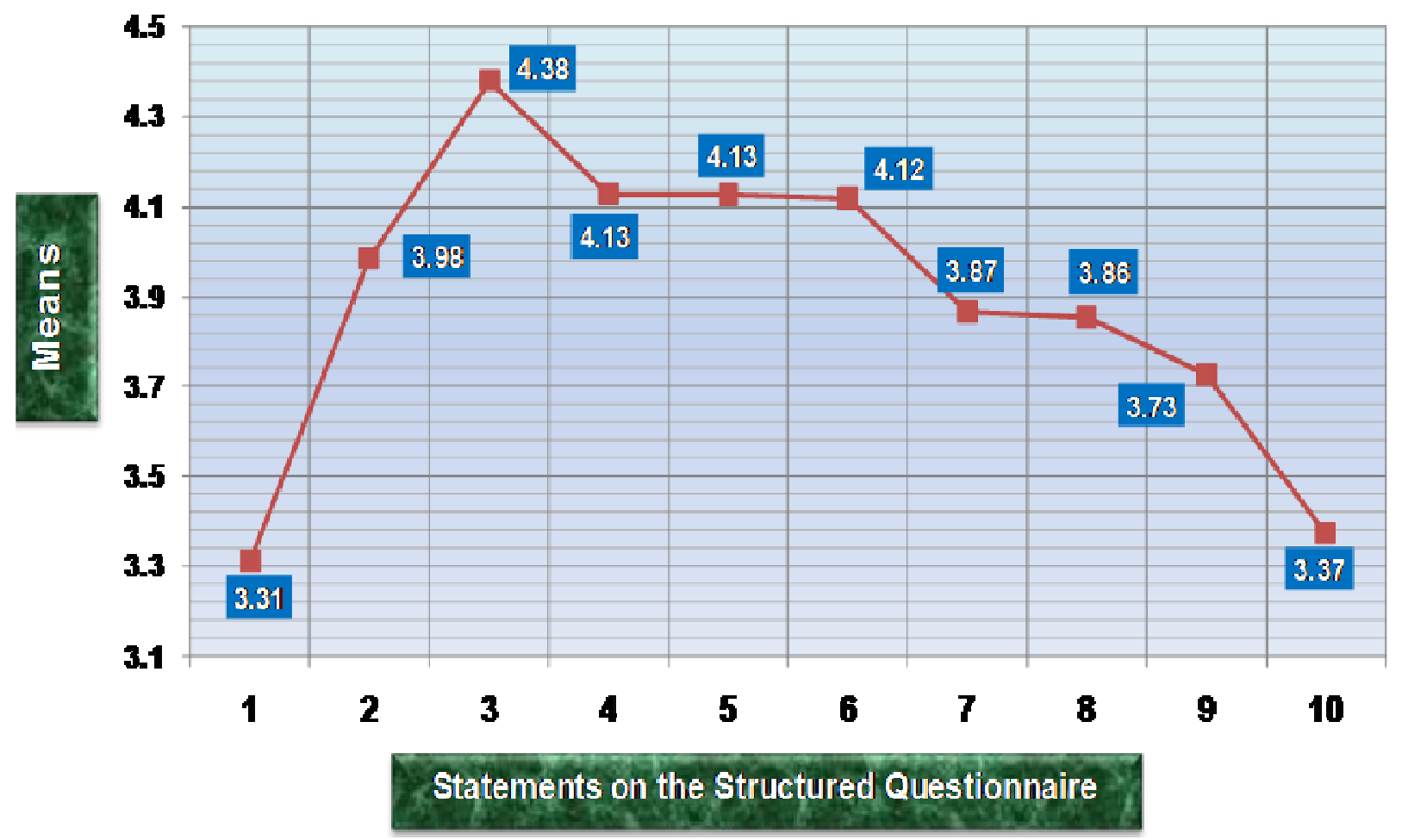

Figure 3. Means of the response ratings of statements on the survey questionnaire. Source: Own observation.

\section{CONCLUSION AND RECOMMENDATIONS}

The balanced scorecard model that was developed by Kaplan and Norton (1992) in the USA was conceptualised based on the maxim of "maximisation of shareholders' wealth" which is in line with the social framework of the Western society. All the other perspectives: learning and growth, internal business processes, and customer perspectives are geared towards achieving this ultimate objective of maximising shareholders' wealth. On the contrary, the African framework is socialist, community-based and humanist in nature. The Africa's corporate governance embraces all stakeholders and that it is premised on the Ubuntu philosophy which is omnipresent throughout the African continent.

The study findings have revealed the socio-cultural disparities between the Western and African frameworks. The findings confirm that an African framework is different from the Western capitalist framework in that its socio-cultural setting is inclusive and stakeholder-centred unlike the exclusive and shareholder-centred of the Western society. Thus, research findings indicate that the current conceptualisation of balanced scorecard model is not fully relevant to an organisation operating in an African environment. The Norton and Kaplan balanced scorecard model is not ideal for an organisation that is operating in Africa.

Further, the findings suggest that there is a need to redesign the current balanced scorecard model to reflect realities of the African socio-cultural framework that is inclusive and stakeholder-centred. The new Africanised balanced scorecard model would represent a more holistic and balanced approach where all stakeholders are embraced unlike the current balanced scorecard model that just focuses on maximisation of shareholders' wealth. Other critical stakeholders such as suppliers, government, debt financiers, competitors, the community and the natural environment are completely ignored or given less emphasis in the current balanced scorecard model. It is envisaged that perspectives of the new Africanised balanced scorecard model would be inclusive and stakeholder-centred rather than the current exclusive shareholder-centred Balanced Scorecard model of Kaplan and Norton.

\section{REFERENCES}

Babbie E, Mouton J (2007). The Practice of social research, Oxford University Press Southern Africa:Cape Town.

Battle M (1997). Reconciliation: The Ubuntu Theory of Bishop Desmond Tutu. Cleveland, $\mathrm{OH}$ : Pilgrim's Press.

Binedell N (1994). Vision and reality: business in the new South African environment. In Christie $P$, Lessem $R$, Mbigi L (eds.), African Management. Johannesburg: Knowl. Resour., pp. 3-14.

Bourguignon A, Malleret V, Norreklit H (2004). The balanced scorecard versus the French tableau de bord: the ideological dimension, Manage. Account. Res., 15: 107-134.

Broodryk J (2007). Ubuntu Management Philosophy. Randburg: Knowres. 
Bryman A, Bell E (2007). Business research methods, Oxford University Press:New York.

Chan YL (2009). How strategy map works for Ontario's health system. Int. J. Public. Sect. Manage., 22(4): 349-363.

Chenhall RH (2005). Integrative strategic performance measurement systems, strategic alignment of manufacturing, learning and strategic outcomes: An exploratory study, Account. Organiz. Soc., 30: 395422.

Costello AB, Osborne JW (2005). Best practice in exploratory factor analysis: Four recommendations for getting the most from your analysis, Pract. Assess. Res. Eval., 10(7): 1-9.

Darley WK, Blankson C (2008). African culture and business markets: Implications for marketing practices, J. Bus. Ind. Mark., 23(6): 374383.

Dasgupta $S$ (2010). A stitch in time saves nine: behind every major business failure lies an untold story. Bus. Strategy. Ser., 11(2): 100106.

David F (2005). Strategic management: concepts \& case studies. Upper Saddle River, NJ: Prentice Hall.

DeBusk GK, Crabtree AD (2006). Does the balanced scorecard improve performance? Manage. Account. Q., 8(1): 44-48.

Dillman DA (2000). Mail and International Surveys: The Tailored Design Method. New York: Wiley.

English $\mathrm{J}$ (2002). Managing cultural differences to improve industrial efficiency, Build. Res. Inform., 30(3): 196-204.

Eze MO (2006). Ubuntu: A Communitarian Response to Liberal Individualism? University of Pretoria: Pretoria.

Field A (2009). Discovering Statistics Using SPSS. London: SAGE

Ghebregiogis F, Karsten L (2006). Human resource management practices in Eritrea: challenges and prospects, Employee Relations, 28(2): 144-163.

Gichure CW (2006). Teaching business ethics in Africa: What ethical orientation? The case of East and Central Africa. Cross Cult. Manag., 12(3): 63-84.

Gouws DG (1996). The role of accounting in equalising Africa's perception on unequal exchanges. Meditari: Res. J. School. Account. Sci. 4: 113-129.

Gray KR, Shrestha NR, Nkasah P (2008). A cross-cultural perspective on management in Kenya, J. Afr. Bus., 9(1): 27-58.

Hanafizadeh P, Sorousha M (2008). A methodology to define strategic processes in organizations: An exploration study in managerial holding companies. Bus. Process. Manage. J., 14(2): 219-227.

Institute of Directors in Southern Africa (2009). The King Report on Corporate Governance for South Africa.

Kaplan RS, Norton DP (1992). The balanced scorecard - measures that drive performance, Jan-Feb, Harv. Bus. Rev., pp. 71-79.

Kaplan RS, Norton DP (2004). Strategy maps converting intangible assets into tangible outcomes. Boston, MA: Harv. Bus. School Press.
Kaplan RS, Norton DP, Rugelsjoen B (2010). Managing alliances with the balanced scorecard. Harv. Bus. Rev., 88(1): 114-120.

Khomba JK (2011). Redesigning the Balanced Scorecard model: an African perspective. A PhD thesis. University of Pretoria, Pretoria. Online available [<http://upetd.up.ac.za/thesis/available/etd10142011-093347/> Accessed 2 ${ }^{\text {nd }}$ January 2012.

Khomba JK, Vermaak FNS, Gouws DG (2011). Redesigning an innovation section of the Balanced Scorecard model: An African perspective [Online Available: http://www.unisa.ac.za/contents/faculties/service_dept/docs/SABVIE W15_3_CHAP1.pdf., South. Af. Bus. Rev., 15(3): 1-20.

Kohnen $J$ (2008). Business process management and the balanced scorecard: Using processes as strategic drivers. Q. Manage. J., 15(1): 76-77.

Mangaliso MP (2001). Building competitive advantage from Ubuntu: Management lessons from South Africa. Acad. Manage. Exec., 15(3): 23-33.

Mangcu X (2007). Visions of Black Economic Empowerment. Pretoria: Jacana.

Mbigi L, Maree J (2005). Ubuntu: The Spirit of African Transformation Management. Randburg: Knowl. Resour.

McFarlin DB, Coster EA, Mogale-Pretorius C (1999). South African management development in the twenty-first century: Moving toward an Africanized model, J. Manage. Dev., 18(1): 63-78.

McNamee PB (1993). Management accounting: strategic planning and marketing. Oxford: Butterworth-Heinemann.

Moloketi GR (2009). Towards a common understanding of corruption in Africa, Public. Policy. Admin., 24(3): 331-338.

Niven PR (2008). Balanced scorecard step-by-step for government and nonprofit agencies. (2 edition), John Wiley \& Sons:New York

Rossouw DJ (2009). The ethics of corporate governance: global convergence or divergence? Int. J. Law. Manage., 51(1): 43-51.

Saunders M, Lewis P, Thornhill A (2003). Research methods for business students, Prentice Hall:Edinburgh, England.

Shubani K (2007). An argument for capital concentration and socially responsible investing. In Mangcu X (ed.), Visions of Black Economic Empowerment (pp.162-173). Pretoria: Hum. Sci. Res. Counc.

Voelpel SC, Leibold M, Eckhoff RA (2006). The tyranny of the Balanced Scorecard in the innovation economy, J. Intellect. Cap., 7 (1): 43-60.

Welman C, Kruger F, Mitchell B (2005). Research methodology, Oxford University Press Southern Africa:Cape Town.

West A (2009). The ethics of corporate governance: A (South) African perspective. Int. J. Law. Manage., 51(1): 10-16.

Wu S, Liu S (2010). The performance measurement perspective and causal relationship for ISO-certified companies. Int. J. Qual. Reliab. Manage., 27(1): 27-47. 


\section{APPENDIX 1}

\section{Survey questionnaire} Background

The African economic landscape is different from that of Western economies where the Balanced Scorecard model originates insofar as infrastructural systems, markets and customers, sources of capital, government interventions, literacy levels, and socio-cultural underpinnings are concerned. The African framework is humanistic, community-based and socialistic in nature. Taking this cognisance, the study aims at establishing relevance of the generic Balanced Scorecard model within an African context.

\section{Instructions}

This questionnaire, though you have to complete it voluntarily, is an important research instrument for the study that I am currently conducting. Please try to respond to ALL statements. For anonymity, please DO NOT provide your name or any form of identification on this questionnaire. Note that your responses will be strictly confidential and will only be used for the purposes of this study and any publications that may arise here from.

\section{Section A: general organisational information}

A1. Name of your organisation (Please fill space provided)

A2. Name of your country (tick/click as appropriate)
1. $\square$ South Africa
2. $\square$ Malawi
3. $\square$ Other (specify)

A3. Indicate whether or not you are using the Balanced Scorecard model (tick/click as appropriate)

1. $\square$ Yes

2. $\square$ No

A4. If yes, indicate how you rate the usefulness of the Balanced Scorecard model towards your operations (tick/click as appropriate)
1. $\square$ Not useful
4. $\square$ Very useful
2. $\square$ Somehow useful
3. $\square$ Useful

A5. Indicate your industry (tick/click as appropriate)
1. $\square$ Agriculture, Forestry \& Fishing
2. $\square$ Mining \& Quarrying
4. $\square$ Electricity, Gas \& Water
7. $\square$ Transport \& Storage
5. $\square$ Construction
8. $\square$ Tourism \& Hospitality
3. $\square$ Manufacturing
10. $\square$ Information \& Communication11.
Financial \& Insurance
6. Wholesale \& Retail trade
9. $\square$ Real estate

A6. Number of employees for your organisation (tick/click as appropriate)
1. $\square$ Less than 101
$2 \square$ From 101-200
5. $\square$ From $401-500$
3. $\square$ From $201-300$
4. $\square$ From $301-400$
8. $\square$ From $701-800$
6. $\square$ From $501-600$
7. $\square$ From $601-700$
11. $\square$ Over 1000
9. $\square$ From $801-900$
10. $\square$ From 901-1000

\section{A7. Your current position (tick/click as appropriate)}
1. $\square$ Senior Management
2. $\square$ Middle Management
3. $\square$ Other (specify)

A8. Number of years you have been in service (tick/click as appropriate)
1. $\square$ Less than 6 years
2. $\square$ From 6 -10 years
4. $\square$ From $16-20$ years
5. $\square$ From $21-25$ years
3. $\square$ From $11-15$ years
6. $\square$ Over 25 years

\section{A9. Indicate ALL stakeholders that deal with your organisation (tick/click as appropriate)}

Stakeholders are groups that have interests or hold stakes in the operations of your organisation.
1. $\square$ Shareholders
$2 \square$ Debt providers
3. $\square$ Customers
4. $\square$ Suppliers
5. $\square$ Competitors
6. $\square$ Management and employees 

7. $\square$ Government
8. $\square$ External auditors
9. $\square$ Regulatory bodies
10. $\square$ Community
11. $\square$ Ecological system
12. $\square$ Other (specify)

\section{Section B: Relevance of the balanced scorecard model}

There are different statements for each of the six scales on this section. In your opinion, tick (hard copy) or click (soft copy) on a level of each continuum that represents the strength of your agreement/disagreement regarding the statements about your organisation.

\section{Ranking key:}

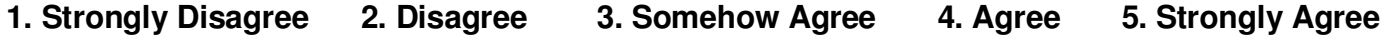

1. Our organisation puts more emphasis on maximisation of shareholders wealth than of other stakeholders wealth

2. We treat employees as the most valuable asset of our organisation

$1 \square \quad 2 \square \quad 3 \square \quad 4 \square \quad 5 \square$

3. We recognise the interdependence of relationships of our stakeholders

$1 \square \quad 2 \square \quad 3 \square \quad 4 \square \quad 5 \square$

4. Our profitability success is a result of inputs from various stakeholders

$1 \square \quad 2 \square \quad 3 \square \quad 4 \square \quad 5 \square$

5. Our primary goal of external reporting is to contribute to an ongoing stakeholder dialogue

6. We treat our suppliers as an integrated part of our business

7. All stakeholders receive sufficient benefits to assure their continued collaboration with our organisation

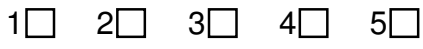

8. We demonstrate mutual respect with our competitors

9. We constantly interact with and help the local community in which we operate

Thank you very much for completing the questionnaire.

E-mail: after saving, email the completed questionnaire as an attachment to jkkhomba@gmail.com or jkkhomba@poly.ac.mw or forward the completed questionnaire (hard copy) to:

Dr J. Kamwachale Khomba

Management Studies Department, University of Malawi, Private Bag 303, Blantyre 3 Malawi. 